Petter Aaslestad

Leder i Forskerforbundet

Professor i litteraturvitenskap,

Norges teknisk-naturvitenskapelige universitet

Foto: Erik Norrud

\title{
Dumhetens triumf
}

\section{Den største litteraturen har}

uendelig levetid, til forskjell fra

de fleste vitenskapelige tidsskrift-

artikler.

Den selvtilfredse apotekeren Homais i den lille landsbyen Yonville, i Gustave Flauberts Madame Bovary (1857), er ifølge ham selv «en varm forkjemper for alt fremskritt». «Han hadde nylig sett lovprist en ny metode å helbrede klumpfot på og [...] fikk den patriotiske idé at de også i Yonville, for å være på høyden, skulle foreta operasjoner av strephopodi» (i Peter Rokseths oversettelse).

Han allierer seg med fru Bovary og antyder at her er sjansen for at hennes ektemann, landsbylegen Charles, endelig kan bli berømt. Charles lar seg til slutt overtale: «Han fikk seg tilsendt doktor Duvals bok fra Rouen, og hver kveld satte han seg til å studere den med hodet mellom hendene.»

Apotekeren overbeviser deretter den motvillige, halte vertshusgutten Hippolyte om at en operasjon vil gi ham nytt liv: «Du vil nesten ikke kjenne det minste ondt, bare et stikk [...]. Deretter forestilte Homais ham hvor meget ledigere og mer gangfør han ville bli, og lot ham tilmed forstå at han ville gjøre større lykke hos kvinnene.»

Charles strever seg gjennom forskningslitteraturen og er til sist klar for operasjonen. Neste dag melder lokalavisen om begivenheten: «Til tross for de fordommer som ennå hviler som et teppe over en stor del av Europa, begynner likevel lyset å trenge igjennom i våre landdistrikter. Således var vår lille by Yonville tirsdag skueplass for et kirurgisk eksperiment.
[...] Det var så vidt det piplet noen bloddråper frem, som for å melde at den gjenstridige sene hadde måttet gi tapt for legekunstens inngrep.»

Men akk, det går koldbrann i benet og Bovary og Homais må tilkalle en lege utenfra: «Det ble en stor begivenhet i landsbyen da doktor Canivet skulle sette av Hippolytes lår!» Til tross for interessen intet nytt oppslag i lokalpressen!

Charles våger seg ikke utendørs. $\mathrm{Og}$ Emma nages over at hun har innbilt seg at ektemannen kunne duge til noe: «som om hun ikke tyve ganger før hadde sett til bunns i hans ynkverdighet.»

Emma drømmer om romantisk kjærlighet slik hun har lest om den i romanene. Hennes kjedsomhet og lengsel bort fra den trøstesløse landsbyen utenfor Rouen er på en og samme tid dypt tragisk og like dypt komisk. «Hun ville på en gang dø og bo i Paris.» Etter flere utroskapshistorier og stort pengeforbruk, med påfølgende utpanting, skaffer hun seg arsenikk hos apotekeren og tar sitt eget liv. Den godmodige, enfoldige, trofaste Charles dør kort tid etterpå.

For apotekeren, derimot, går det godt. Til myndighetene anfører han at han har gitt ut det allmennyttige verket $0 \mathrm{~m}$ eplemosten, dens fremstilling og virkninger. Effekten blir som han håper på - i romanens siste setning tildeles han ÆEreslegionen.

Jeg liker dårlig å sette enkeltepisoder av litterære verk i analogisk forbindelse med vår egen virkelighet. Men her er fristelsen for stor:

Den grenseløse forfengelighet, koblet med positivistisk fremskrittsoptimisme, som apotekeren ligger under for, er ikke avgrenset til den franske landsbygda på midten av det nittende århundre: Den såkalte Macchiarini-saken ved Karolinska institutet har avdekket CV-forfalskning og gigantisk forskningsjuks, og både rektorer, direktører og flere medlemmer av den inntil nå så aktverdige nobelkomiteen i medisin har måtte gå fra sine stillinger.

Men forskningsjuks er ikke bare et utenlandsk fenomen: Nylig presenterte professorene Bjørn Hofmann \& Søren Holm i herværende tidsskrift en undersøkelse om forskningsetiske holdninger hos ph.d.-kandidater i medisin. Der fremkommer det at så mange som hver tiende kandidat er villig til å falsifisere, fabrikkere eller utelate data. Hva i all verden er det som skjer? Er forskningens sannhetssøken i ferd å bli erstattet med narsissistiske og forfengelige drømmer om rikdom og berømmelse, slik Flaubert på så kostelig vis får frem i Madame Bovary?

Det viser seg at Flauberts innsikter går dypere enn til analoginivået. Selvsagt visste man også før ham at dumheten eksisterte, men man forsto dumhet som fravær av kunnskap, som noe som kunne rettes ved opplysning. Hos Flaubert, derimot, er dumheten en del av selve den menneskelige eksistens. Dumheten utvikler seg parallelt med fremskrittet. Dette har Milan Kundera kalt det nittende århundrets mest sjokkerende oppdagelse. I dagens forskningsverden, med dens overspente retorikk om fremragende forskning og gjennombrudd, er det øyeblikk hvor man kan tro at Flaubert er glemt. Homais, derimot, er igjen klar til å motta Æreslegionen.

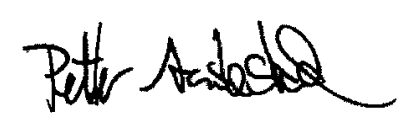

